IZA DP No. 9454

Welfare Implications of India's Employment

Guarantee Programme with a Wage Payment Delay

Parantap Basu

Kunal Sen

October 2015 


\title{
Welfare Implications of India's Employment Guarantee Programme with a Wage Payment Delay
}

\author{
Parantap Basu \\ Durham University Business School \\ Kunal Sen \\ IDPM, University of Manchester \\ and IZA \\ Discussion Paper No. 9454 \\ October 2015
}

\author{
IZA \\ P.O. Box 7240 \\ 53072 Bonn \\ Germany \\ Phone: +49-228-3894-0 \\ Fax: +49-228-3894-180 \\ E-mail: iza@iza.org
}

Any opinions expressed here are those of the author(s) and not those of IZA. Research published in this series may include views on policy, but the institute itself takes no institutional policy positions. The IZA research network is committed to the IZA Guiding Principles of Research Integrity.

The Institute for the Study of Labor (IZA) in Bonn is a local and virtual international research center and a place of communication between science, politics and business. IZA is an independent nonprofit organization supported by Deutsche Post Foundation. The center is associated with the University of Bonn and offers a stimulating research environment through its international network, workshops and conferences, data service, project support, research visits and doctoral program. IZA engages in (i) original and internationally competitive research in all fields of labor economics, (ii) development of policy concepts, and (iii) dissemination of research results and concepts to the interested public.

IZA Discussion Papers often represent preliminary work and are circulated to encourage discussion. Citation of such a paper should account for its provisional character. A revised version may be available directly from the author. 


\section{ABSTRACT \\ Welfare Implications of India's Employment Guarantee Programme with a Wage Payment Delay*}

We examine the efficacy of a popular anti-poverty programme, namely the National Rural Employment Guarantee Act (NREGA) of the Government of India. We argue that a chronic friction of wage payment delay in this flagship programme could adversely affect the welfare of the poor through two channels. First, it causes deferred consumption. Second, it turns labour into a credit good which makes an indebted household work harder to clear off his existing debt. The loss of welfare persists even when the worker has an outside employment option. If a programme of financial inclusion increases the indebtedness of the poor, a wage payment delay in the NREGA programme could escalate this welfare loss although the official indicator of success (i.e., participation) may not reveal this friction.

JEL Classification: H53, O11, J43

Keywords: NREGA, employment guarantee, credit good, financial inclusion

Corresponding author:

Kunal Sen

Institute of Development Policy and Management

University of Manchester

Oxford Road

Manchester M13 9PL

United Kingdom

E-mail: kunal.sen@manchester.ac.uk

\footnotetext{
* We owe Subhasish Dey for processing the data. Leslie Reinhorn, Anurag Banerjee, and especially Bibhas Saha are acknowledged for helpful discussion and comments. We also thank the participants of the PET conference in 2015 for helpful feedback. The usual disclaimer applies.
} 


\section{Introduction}

The aim of this paper is to analyze the welfare effects of wage payment delay in a popular employment guarantee programme in India known as the Mahatma Gandhi National Rural Employment Guarantee Scheme (NREGA hereafter). The issue is important because this programme has received increasing attention in recent years as a workfare programme that targets the poor (Lal et al. 2010, Subba Rao et al. 2013). A large literature has examined the efficacy and welfare implications of such anti-poverty programmes (Besley and Coate 1992, Dreze and Sen 1991, Lipton 1996, Ravallion 1991). Basu, Chau and Kanbur (2009) provide deep theoretical insights about the rationale for such an employment guarantee programme to alleviate frictional unemployment originating from the private labour market due to low labour productivity or high cost of job creation.

While there is no dispute that workfare programmes serve a useful role in correcting private labour market frictions, what is less evident is how it functions when there are persistent frictions in such programme itself. In this paper, we focus on one such friction namely, a delay in the payment of wages to NREGA participants. A key institutional bottleneck has been the significant delay by the government in processing timely wage payment of rural household workers. In principle, workers are promised a payment of NREGA wages through nominated bank accounts or post office accounts within 14 days of completion of the public works project (Government of India, 2013). In practice, workers face delays in payment of wages upwards ranging from 30 to over 90 days.

In addition to the NREGA, the Government of India has almost simultaneously launched another major anti-poverty programme known as Jan Dhan Yojana. The aim of this scheme is to provide the unbanked section of the population wider access to banking and financial services. Various measures were undertaken by the Reserve Bank of India to lower the transaction and administrative costs for the poor to open savings accounts which effectively boost the real rate of return on saving encouraging more saving. Simultaneously there was greater proliferation of micro-finance institutions (MFI) with an aim to provide multipurpose loans to the poor. 
Little attention is devoted in the literature to understand the effect of NREGA wage payment delay on the welfare of the poor particularly in a policy environment of greater financial inclusion of the poor. Our paper precisely aims to address this question. Our study is motivated by two key counter-intuitive stylized facts based on the district level data for India that we report later. First, a higher payment delay is uniformly associated with a greater NREGA participation. Second, NREGA participation responds more positively to wage payment delay particularly in districts with greater financial inclusion.

Why is financial inclusion of the poor an issue while assessing the efficacy and welfare implications of NREGA programme? While the aim of financial inclusion is to provide the poor wider access to financial markets and reduce their dependence on local money lenders, studies show mixed evidence about the success of this programme across regions. During the same period when the programme of financial inclusion is in place, rural households' indebtedness and default also increased accompanied with a greater proliferation of MFI. Greater default led to a rise in the borrowing cost of the households giving rise to a vicious circle of poverty and indebtedness. The most recent survey of agricultural households by the National Sample Survey Office (NSSO) shows that about $51.9 \%$ agricultural households are considered to fall in the indebted category (Sangwan 2015). One possible reason for such increasing indebtedness is the increasing loan pushing by microfinance organizations to poor rural farmers and the high interest rates charged on these loans (Hulme and Maitrot 2014).

Using a stylized life cycle model, we demonstrate that if financial inclusion elevates the indebtedness of the poor, it may induce the borrower/worker to participate more in the NREGA programme to clear off his debt burden and entangle him more in a poverty trap with onerous workload. The underlying intuition of our key result stems from the fact a payment delay makes labour a credit good. A longer payment lag lowers the present value of labour income flows because it lowers the discount factor facing the household. The borrower/worker has to make a credible promise to the lender to work harder to pay off his debt. This raises his participation in the NREGA 
programme. Greater disutility of work coupled with deferred consumption lowers the steady state welfare and makes the household worker worse-off.

A higher NREGA participation of rural workforce would then be a misleading indicator of success of the workfare programme because it would not necessarily reveal the welfare loss suffered by the asset-poor households who face a formidable wage payment delay. The welfare assessment of employment guarantee of the poor in the presence of wage payment delay and financialization of the poor is new in the growing literature on workfare. ${ }^{1}$ In this respect our study is novel.

To check the robustness of our key theoretical result, we examine the NREGA labour supply response of the poor when they have other employment options with no wage payment delay besides NREGA. We extend our model to include a private labour market where the wage in the private labour market is competitively determined. The outside employment option of the poor depends on the availability of such private jobs that could vary between lean and peak seasons. In a lean season, when these private employment opportunities dry up, the same positive relationship between payment delay and worker's NREGA participation of the asset poor household emerges. Despite the flexibility of work allocation, households are still worse off in terms of welfare when payment delay is longer because it distorts their work allocation decision.

Although the availability of private labour market options weakens the relationship between payment delay and NREGA participation, in reality poor households with low productivity have very limited outside options. Thus it is likely that asset-poor households would participate more in NREGA when payment delay is longer to clear off his debt burden. ${ }^{2}$

The rest of the paper is organized as follows. In section 2, we give a brief historical sketch of the institutional bottlenecks in NREGA that gave rise to the payment delay. Section 3 presents some stylized facts on the relationship between NREGA participation, payment delay and the extent of financial

\footnotetext{
${ }^{1}$ Hereafter, we use the phrase financialization and financial inclusion of the poor synonymously although there may be subtle differences between these two policies which is not pertinent to our analysis.

${ }^{2}$ Desai et al. (2015) document that the poor are more likely to participate in NREGA.
} 
inclusion. In section 4, we develop a stylized life cycle model and some simulation results to demonstrate the relationship between wage payment delay and NREGA participation in alternative labour market scenarios. Section 5 concludes.

\section{Evolution of Wage Payment Delay in NREGA}

The NREGA is India's main welfare programme for the rural poor and the largest workfare programme in the world, covering 11 per cent of the world's population (Muralidharan et al. 2015). The programme started in the financial year 2005-2006 and was rolled out in phases. Initially restricted to the 200 poorest districts of India in 2006, it was extended to 130 more districts in 2007 and to all districts in the country in 2008. The programme budget in the financial year 2013-2014 was USD 5.5 billon, or 7.9 per cent of the Indian government's budget. The programme has uneven success across the country (Banerjee et al. 2014, Desai et al. 2015).

Since there is no eligibility requirements for the NREGA programme because of the manual nature of the work involved, the poor participate more in this programme (Besley and Coate 1992). Participating households obtain job cards, which are issued by the local Gram Panchayat (GP, or village office). Once issued a job card, workers can apply at will to the local GP or block office, the lowest and next lowest units in the administrative hierarchy. Officials are legally obligated to provide work on projects within 5 kilometres of the worker's home. The projects vary greatly, though road construction and irrigation earthworks predominate (Niehaus and Sukhtankar 2013). Households work in NREGA projects at stipulated wages set at the state level. The supply of labour from the household for NREGA project occurs mostly in the lean (dry) season, when alternative private sector casual jobs are not available, while it tails off in the peak (rainy) season (Imbert and Papp 2015). ${ }^{3}$ The administration of the projects is run by the key officials of GP who are the elected Sarpanch (or village leaders) and the appointed

\footnotetext{
${ }^{3}$ According to the 2007-2008 National Sample Survey of the Indian government, rural adults spend on average 1.5 per cent of their time on public works during the lean season and less than 0.5 per cent of time during the peak season.
} 
Panchayat Secretaries. Project work-sites are managed by officials called Field Assistants, who record attendance and output on "muster rolls" and send these to the sub-district for digitization. Work records are then sent to the state level which triggers the release of funds to pay workers.

In the first two years of the programme, payments to workers were often made in cash in several states in India. Under the system of cash payments, wages were paid by the same agency that was responsible for implementing the NREGA (that is, the GP), leading to the embezzlement of funds, with corrupt officials able to inflate muster roll entries and retain the funds that were supposed to be paid to workers (Khera 2010). However, in response to widespread media coverage of corruption in NREGA, in 2008 the Government of India instructed state government to move to a system of wage payments through bank or post office accounts set up for workers (Adhikari and Bhatia 2010). The immediate rationale for the shift to payments through banks and post offices was to make sure that an independent financial institution is responsible for payments to workers without any outside interference. Finally, an important complementary objective of the shift to payments through banks was to include rural workers in the formal financial sector in order to develop their saving propensity for the future. Therefore, the switch from cash to bank payments was seen by the Government of India as "the world's largest financial inclusion scheme" (Government of India 2015).

However, the shift from the cash to bank payments unfortunately led to long and variable payment delays to workers (Khera 2010). Initially this delay was due to the huge surge in the number of accounts that had to be opened in banks and post offices for NREGA workers. A complex bureaucratic system then emerged in the approval of payments. Lists of wage payments of individual workers are prepared by the Field Assistants in charge of the projects. Officers at the block and district (the next highest level of the administrative hierarchy after the block) then approve the payments list. It then goes to the bank officer (at the state or central level) who processes the payment, transferring the payment due to the worker from the GP's bank account to the worker's bank account (usually the worker's 
and GP's account are in the same bank). Delays may occur at every each stage of the payment process with GPs entirely dependent on higher level functionaries to push funds into their accounts (Banerjee et al. 2014). In 2013-2014, on the average it took about 43 days for workers to receive their wages on completion of their projects, far exceeding the stipulated time prescribed by the Government of India of 14 days (our calculations, from the data obtained from www.mgnrega.nic.in). ${ }^{4}$

\section{Payment Delay, Financial Inclusion and NREGA Participation: Some Stylized Facts}

In this section, we examine the relationship between household labour supply for the NREGA and the wage payment delay. The role of financial inclusion in mediating this relationship is also examined. Data for household labour supply for the NREGA (i.e. NREGA participation) come from the NREGA data portal of the Government of India (website: www.nrega.nic.in). ${ }^{5}$

Financial inclusion is a multi-dimensional notion and thus various definitions can be found in the literature. ${ }^{6}$ Given the caveat that there is no unambiguous measure of financial inclusion, we use the official Crisil index as a proxy of such financial inclusion. ${ }^{7}$ To measure financial inclusion, we use the composite score of financial inclusion calculated for most districts in India by the Indian credit rating agency, Crisil, for the year 2011 (Crisil, 2013). This measure goes from 0 (low financial inclusion) to 100 (high financial inclusion) and is a simple average of three sub-indicators: (a) degree

\footnotetext{
${ }^{4}$ The delay in the payment of wages is particularly evident in the poorer states of India, due to a weak institutional environment in these states. For example, in Bihar, during the financial year 2013-14, 24 per cent of payment transactions were delayed over 90 days and 50 per cent of payments were delayed by more than 14 days.

${ }^{5}$ We use data from 2013-2014 to match it with the wage payment delay data.

${ }^{6}$ See Nair and Tankha (2014) for a comprehensive list of definitions.

${ }^{7}$ The degree of bank penetration is measured by the number of bank branches and number of loan accounts, per hundred thousand population; the degree of credit penetration is measured by the number of small borrower loan accounts and number of agricultural advances, per hundred thousand population; and the degree of depositor penetration is measured by saving deposit accounts, per hundred thousand population.
} 
of bank penetration in the district, (b) degree of credit penetration, and (c) degree of deposit penetration (Crisil 2013). The measure captures both the borrowing and saving dimensions of financial inclusion. In other words, the measure is higher when more households borrow from the formal financial system, and/or when more households save in the formal banking system. After matching the Crisil data with the NREGA participation and wage payment data, we have observations for 498 districts in all 15 major Indian states.

Figure 1 plots the kernel density of NREGA participation of all districts in our sample. The median proportion of participating households among total households registered for the scheme in a given district is 0.30 , with a minimum of 0.03 , a maximum of 0.82 , and a standard deviation of 0.17 .

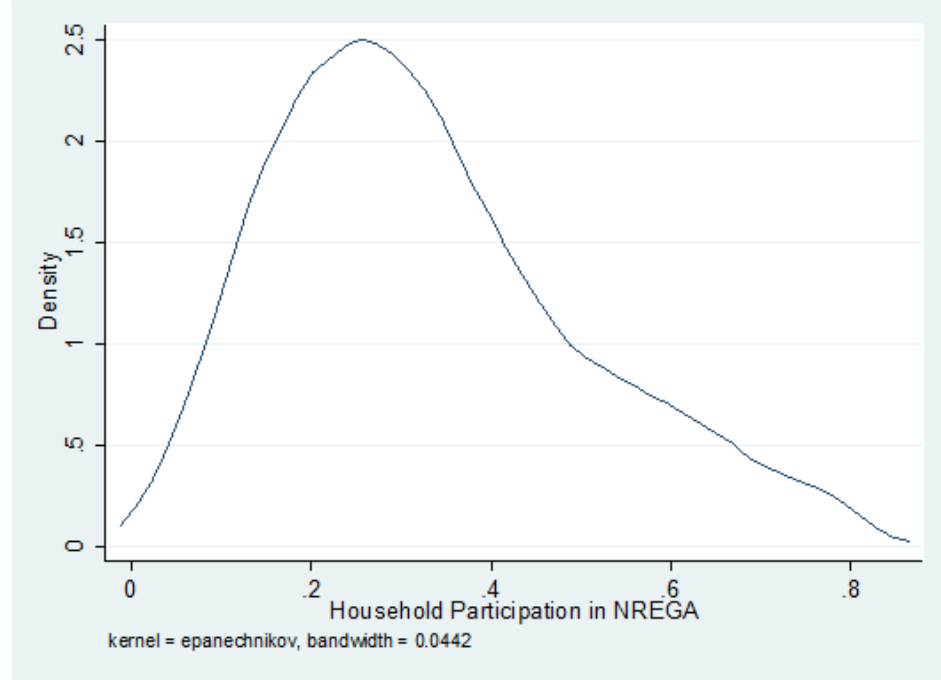

Figure 1: NREGA participation of a sample of 498 Districts in 15 Indian States

Data on wage payment delay also came from the Government of India's NREGA data portal, and is only available for most districts for 2013-2014. For each district, the NREGA data portal provides the number of delayed transactions in interval classes: delay in payment between 15 to 30 days, 30 to 45 days, 45 to 60 days, 60 to 90 days and over 90 days. We compute the average expected delay in payment by taking the average of the midpoints 
of the interval classes, weighted by the proportion of transactions in each interval class in total NREGA transactions in the district. ${ }^{8}$

Figure 2 plots the probability of such delayed payments based on the same sample of districts. The median probability of delay (more than 15 days) of all the payments based on district level estimation is about $50 \%$.

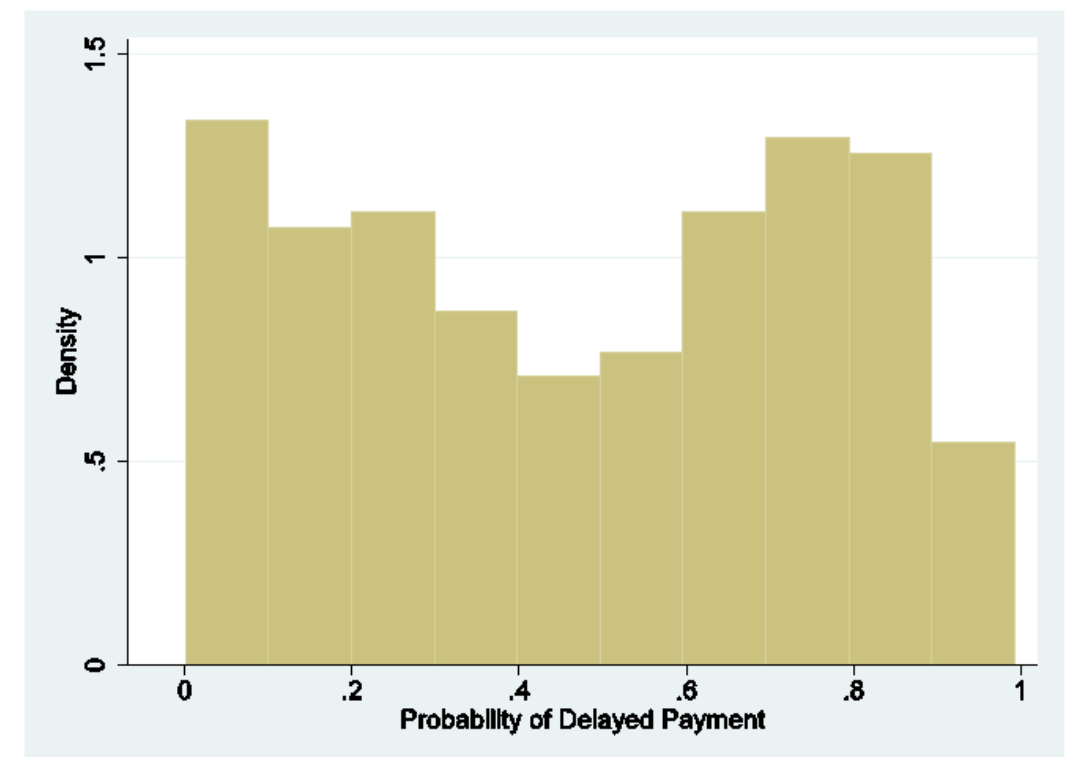

Figure 2: Probability of Payment Delay for 15 states in India, 2012-14.

To explore the relationship between household participation in the NREGA and expected delay in receiving NREGA wages, we run the following regression:

$$
d_{i}=a_{0}+a_{1} W P_{i}+a_{2} Z_{i}+u_{i}
$$

where $d_{i}$ is the proportion of households in the $i$ th district participating in the NREGA among total households registered for the scheme, ${ }^{9} W P_{i}$ is the

\footnotetext{
${ }^{8}$ We also use value of transactions in each interval class instead of number of transactions as the weights to calculate expected delay in payment and get no difference in our results.

${ }^{9}$ Not all households who register for the scheme (i.e., obtain a job card) have intentions of working for the NREGA. Job cards are seen as another form of government identity and by 2013, a significant proportion of rural households, including non-poor households, obtained such job cards (Desai et al. 2015).
} 
delay in NREGA wage payments, $Z_{i}$ is a vector of controls, and $u_{i}$ is the error term.

We include the control set $Z_{i}$ in (1) that may influence household NREGA participation at the district level. The most important of these factors is rainfall variation across districts. Household participation in the NREGA is likely to be higher in districts of India short of rainfall where agricultural activities are not profitable, leading to low private demand for agricultural labour (Dasgupta 2014). To capture rainfall variations across districts, we construct an index which captures rainfall in the district and is constructed from the precipitation data available from the Center for Climatic Research at the University of Delaware. The data include monthly precipitation values at 0.5 -degree intervals in latitude and longitude. To match these data at the district level, the nearest latitude-longitude to each district head quarter is taken. We take the long-term (1990-2008) average district-level rainfall in the monsoon months of July-September.

In addition to the rainfall variable, we include state-level fixed effects to capture large differences across Indian states that have been observed in the implementation of the NREGA (Imbert and Papp 2015). ${ }^{10}$ Finally, we include a battery of district-level controls that capture the level of village infrastructure and social backwardness that may be correlated with district level economic activity and local private demand as well as the ease at which poor agricultural households may be able to find outside work in the private labour market. These measures are the proportion of villages in total inhabited villages with drinking water, electricity, on a bus route, with paved roads, and with a post and telegraph office. Social backwardness variables are the proportion of households which are Scheduled Castes, proportion of households which are Scheduled Tribes, and the proportion of total workers which are marginal workers. Scheduled Castes and Scheduled Tribes are among the poorest in India (Gang et al. 2008), and the Government of India

\footnotetext{
${ }^{10}$ Seven Indian states are seen as top performers, namely Andhra Pradesh, Chhatisgarh, Himachal Pradesh, Madhya Pradesh, Rajasthan, Uttarkhand and Tamil Nadu. Differences in state-level implementation can be explained by a combination of factors such as political will, existing administrative capacity and previous experience in providing public works (Imbert and Papp 2015).
} 
specifically targeted these households for NREGA work. Marginal workers are agricultural labourers, who are the poorest occupational group in India, and in need of NREGA work the most (Roy 2015). All the village variables are obtained from the 2001 Census of India, while the social backwardness variables are obtained from the 2011 Census of India.

Next, we examine whether the relationship between NREGA participation and wage payment delay would differ by the level of financial inclusion in the district. Denoting financial inclusion index as $F$, districts with $F$ greater than the median $F$ are labelled as "high financial inclusion districts and remaining districts are deemed to be "low financial inclusion" category. We run separate regressions (1) for these two subsamples of districts to see if the coefficient on wage payment delay, $W P$, differs by the level of financial inclusion of the district.

Table 1 reports the salient regression results. In Col. (1), we present an estimate of equation (1) with only state fixed effects as controls. We treat payment delay as an exogenous variable as we have seen in the earlier section that it is mostly caused by bureaucratic inefficiencies at the district level. The coefficient of the expected delay in wage payment is positive and significant at the 1 per cent level. In Col. (2), we introduce rainfall as an additional control, and in Col. (3), we introduce all other controls. The sign and significance on the wage payment variable does not change in these two augmented specifications. The regression results reported in Col. (4) and (5) refer to high and low financial inclusion districts. The coefficient of wage payment is positive and significant for the "high financial inclusion" districts but is insignificant for the "low financial inclusion" districts. This suggests that the positive relationship between participation in the NREGA and wage payment delay holds mostly for financially included districts.

In sum: two stylized facts emerge from our empirical exercise based on district level data. First, households participate more in NREGA projects in districts with greater wage payment delay. Second, they participate more in districts with higher levels of financial inclusion. In the next section, we develop a simple life cycle model to understand these empirical regularities.

$<$ Insert Table $1>$ 


\section{The Model}

Consider an economy where the rural household receives a stationary endowment (nonlabour income), $y^{i}$ each period. The household receives utility from consumption, $c_{t}^{i}$ and suffers disutility from work effort. $l_{t}^{i}$. The household has an option to work for NREGA at a fixed contract wage $w$ or not to work and consume the endowment every period. We call $l_{t}^{i}$ the labour supply in NREGA. In this baseline model we assume that besides NREGA there is no private labour market option available to the household. The only outside option besides work is to fall back on consuming the endowment $y^{i}$. Similar to Kollmann (2002) let the instantaneous utility function be $\ln \left(c_{t}^{i}-\bar{c}\right)-A l_{t}^{i}$ where $\bar{c}=$ subsistence consumption. ${ }^{11}$ There is a $k$-period delay in the wage payment for the NREGA service that the household renders at date t. If $k=1$, it means no delay. Household's labour supply is thus a credit good.

Participation in NREGA provides the rural household an access to a bank account which means that in principle all households have an access to the credit market to borrow or lend at a riskfree interest rate $r$. The household solves the following maximization problem:

$$
\begin{gathered}
\operatorname{Max} \sum_{t=0}^{\infty} \beta^{t}\left[\ln \left(c_{t}^{i}-\bar{c}\right)-A l_{t}^{i}\right] \\
c_{t}^{i}+b_{t}^{i}(1+r)=y^{i}+w l_{t-k+1}^{i}+b_{t+1}^{i} \\
l_{t}^{i} \leq \bar{l}
\end{gathered}
$$

Note that $b_{t+1}^{i}=$ the new loans of the household at date t, $r$ is the interest rate which is assumed to be the same as $(1 / \beta)-1 .^{12} \bar{l}$ is the upper limit to

\footnotetext{
${ }^{11}$ We assume that labour is supplied at an extensive margin which means that $l_{t}^{i}$ is the number of household members participating in the NREGA programme supplying a fixed number of work hours. Greater household participation takes household members away from home production which lowers the household's direct utility. This explains why labour appears with a negative sign in the direct utility function. In the appendix, we also work out the case of labour supply at an intensive margin.

${ }^{12}$ To ensure a steady state, hereafter we assume that the rate of time preference is the
} 
NREGA work stipulated by the government. Let $b_{0}^{i}$ be initial indebtedness of the household. We also assume a no-Ponzi game condition which rules out an exploding debt.

The steady state consumption and labour supply functions given by the following proposition. ${ }^{13}$

Proposition 1 The steady state consumption and labour supply depends on the payment lag and the initial level of indebtedness of the household as follows:

$$
\begin{gathered}
c^{i}(k)=\left[\bar{c}+A^{-1} \beta^{k-1} w\right] \\
l^{i}(k)=\min \left[\bar{l},\left\{\frac{\left(\bar{c}-y^{i}\right)}{(1-\beta)} \frac{\beta\left(\beta^{-k}-1\right)}{w}+\frac{1-\beta^{k}}{(1-\beta) A}+\frac{b_{0}^{i}\left(1-\beta^{k}\right)}{\beta^{k} w}\right\}\right]
\end{gathered}
$$

Proof: Appendix.

It is straightforward to verify from (5) the following key result.

Proposition 2 If $y^{i}<\bar{c}$ and $b_{0}^{i}>0$, rural poor participate more in the NREGA programme in response to a longer payment delay.

If the adult is income and asset poor in the sense that his non-labour income $y^{i}$ is less than his subsistence consumption, $\bar{c}$, and $b_{0}^{i}>0$, he has to participate in NREGA to meet his ends because he has no other outside employment option. The present value of labour income given that there is a payment lag $k$ is given by:

$$
\frac{w l^{i}(k)}{(1+r)^{k-1}}\left[1+\frac{1}{(1+r)^{k}}+\frac{1}{(1+r)^{2 k}}+\frac{1}{(1+r)^{3 k}}+\ldots . . \infty\right]
$$

A longer payment lag $(k)$ means that the present value of this wage income flows is lower. If the worker/borrower has an outstanding debt $b_{0}^{i}$ to repay, same as the rate of interest.

${ }^{13}$ Alternative paths of labour supply can also be equilibrium. However, we only focus on a steady state path of $l^{i}$. 
he has to exert higher work effort to clear off this debt burden. ${ }^{14}$ Similar reasoning applies to understand why households with low income $\left(y^{i}\right)$ participate more in NREGA.

The key result that a household poor in income and asset supplies more labour in response to a longer payment delay in the steady state is robust when the household chooses labour at an intensive margin. The appendix works out the case when the household supplies labour at an intensive margin.

\subsection{Welfare effects of an increase in payment lag}

The steady state welfare is function of payment lag $(k)$ which we call $W^{i}(k)$ as follows ${ }^{15}$ :

$$
W^{i}(k)=\frac{1}{1-\beta}\left[\ln \left(A^{-1} w\right)+(k-1) \ln \beta-A l^{i}(k)\right]
$$

The comparative statics effect of a change in $k$ on the life time welfare of the household is:

$$
W^{i \prime}(k)=\frac{1}{1-\beta}\left[\ln \beta-A l^{i \prime}(k)\right]
$$

Since $l^{i}(k)$ is increasing in $k$ as seen in proposition $2, W^{i}(k)$ is unambiguously decreasing in $k$. We summarize this key result as follows.

Proposition 3 If $y^{i}<\bar{c}$ and $b_{0}^{i}>0$, the payment delay unambiguously lowers the steady state welfare of borrower/households.

\footnotetext{
${ }^{14}$ It is straightforward to work out the solution of no payment delay when $k=1$ which are as follows:

$$
c^{i}=\bar{c}+A^{-1} w
$$$$
l^{i}=\frac{\bar{c}-y^{i}}{w}+\frac{1}{A}+\frac{r b_{0}^{i}}{w}
$$

In the absence of payment delay, labour supply is a "cash good" and it is independent of the interest rate.

${ }^{15}$ To obtain (6), plugging (4) and (5) into (2).
} 


\subsection{Debt, NREGA Participation and Welfare}

The positive relationship between payment delay and NREGA participation is based more on the assumption that the household's initial asset position is negative than the fact that his non-labour income is insufficient to cover his subsistence consumption. Figures 3 and 4 plot the relationship between payment delay and the NREGA participations of two households $i$ and $j$ who differ in asset status, namely $b_{0}^{i}=100$ and $b_{0}^{j}=-5$ respectively, with $y^{i}=y^{j}>\bar{c} \cdot{ }^{16}$ The household/borrower increases his labour supply in response to longer payment lag. On the other hand, the household/lender increases NREGA participation only up to some threshold payment lag. Once the payment lag exceeds 2 periods, he cuts back NREGA participation and falls back more on his outside options of non-labour income and asset income to smooth consumption.

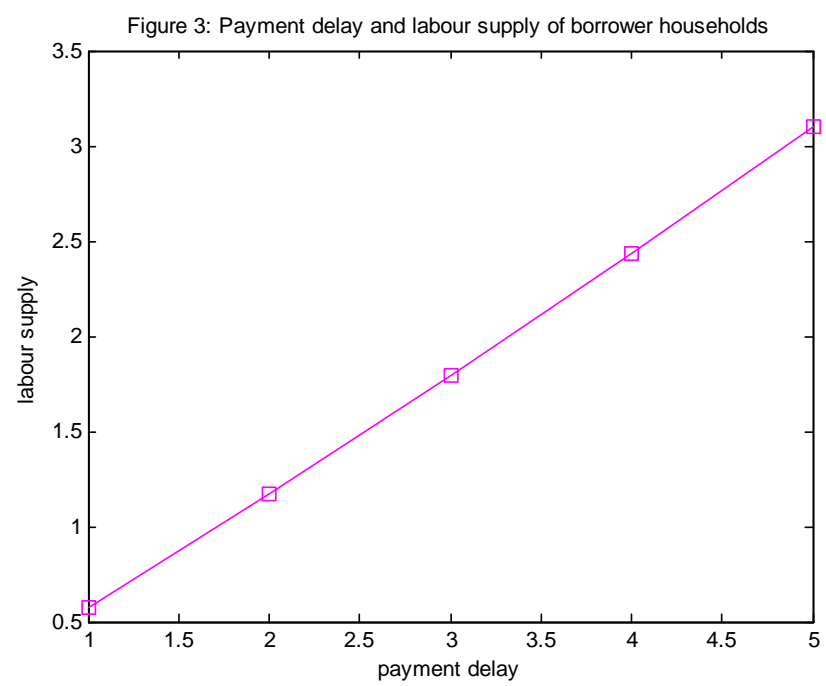

\footnotetext{
${ }^{16}$ For the sake of illustration, we set the parameters as follows: $\beta=0.95$ which means steady state real interest rate of $5 \%, \mathrm{w}=10, \bar{c}=1, y^{i}==y^{j}=1.5, A=10$. These parameters are fixed to get an interior solution for plausible labour supply. The direction of comparative statics reported in Figures 3 through 7 are robust to alternative choices of parameter values except the level of debt $b_{0}^{i}$ and the interest rate, $r$.
} 

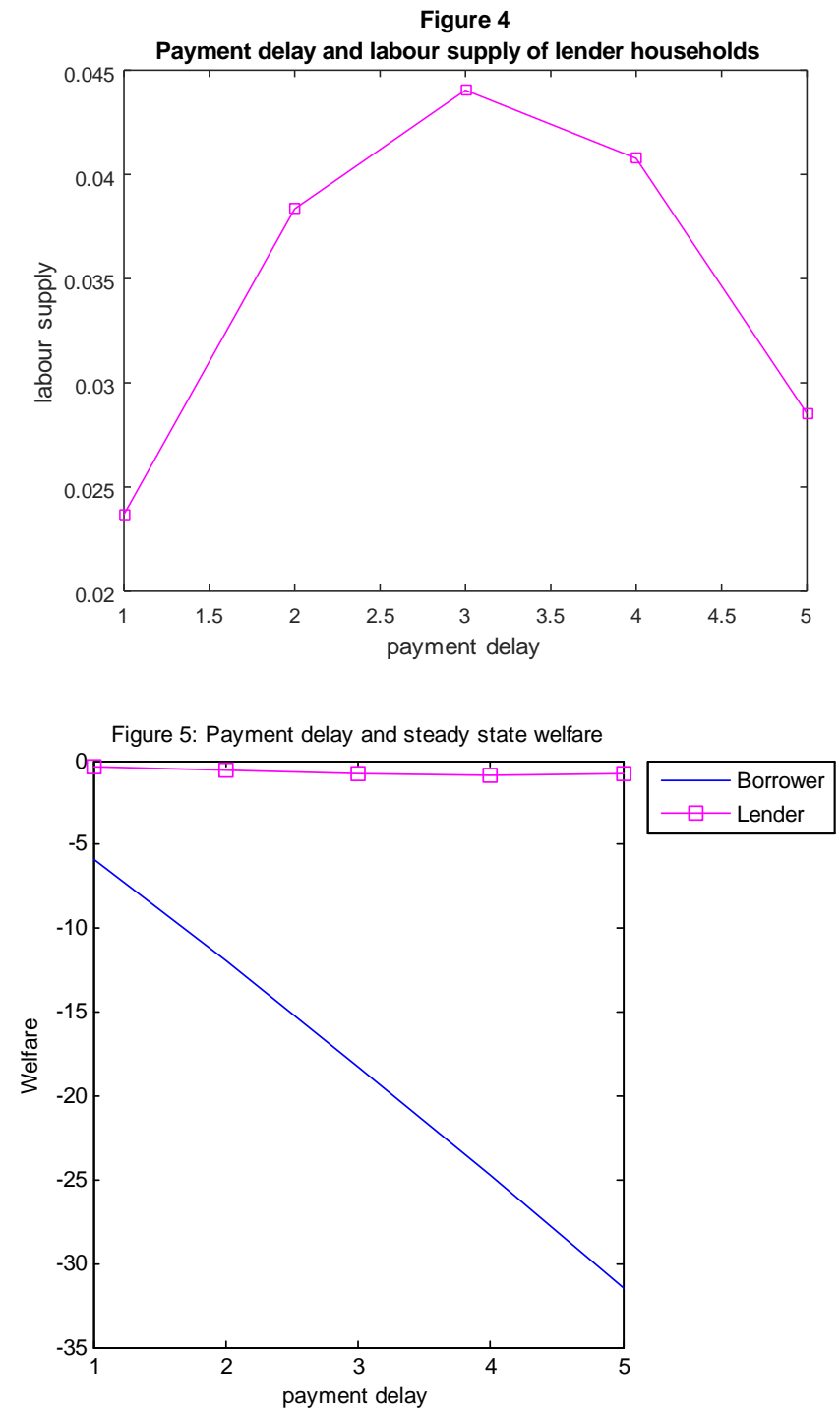

Figure 5 plots the corresponding changes in welfare of these two types of households. A longer payment lag taxes the labour income of all households and thus everybody suffers welfare loss. However, the borrower-household suffers most because of his greater workload in response to payment delay. The lender-household suffers welfare loss primarily due to deferred consumption. 
Figures 6 and 7 plot the same relationships for two different interest rates for the borrower-household only. Higher interest rate by raising the adult's debt retirement cost raises the labour supply and lowers his steady state welfare. This happens progressively more for longer payment lag because the annuity value of wage payment goes down more sharply as the payment lag increases.

Figure 6

Payment delay and labour supply of borrower households

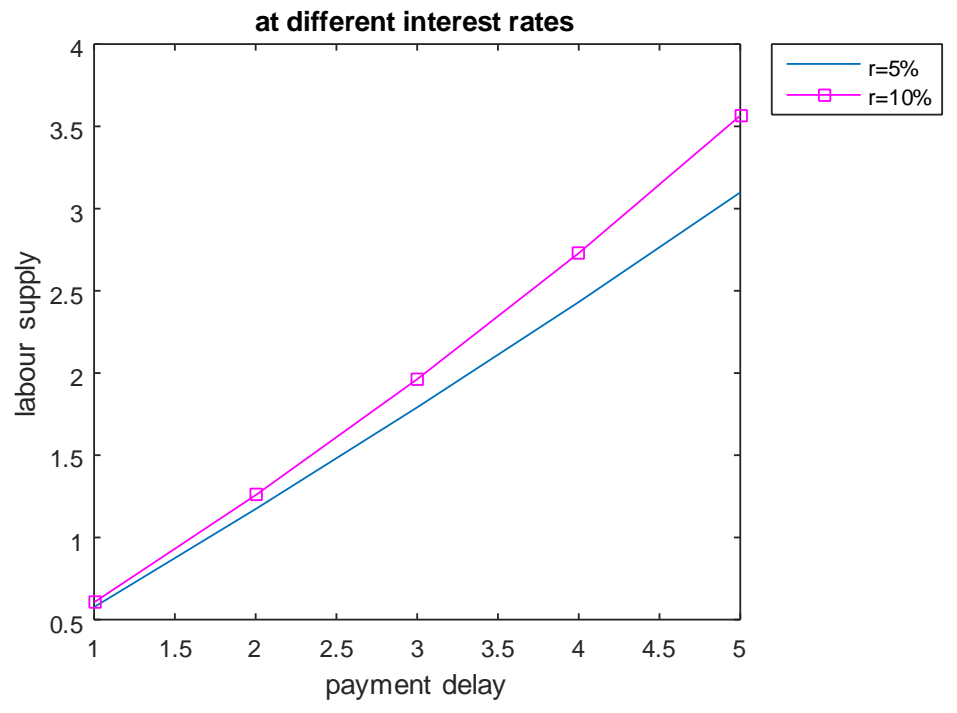


Figure 7

Payment delay and steady state welfare of borrower households

at different interest rates

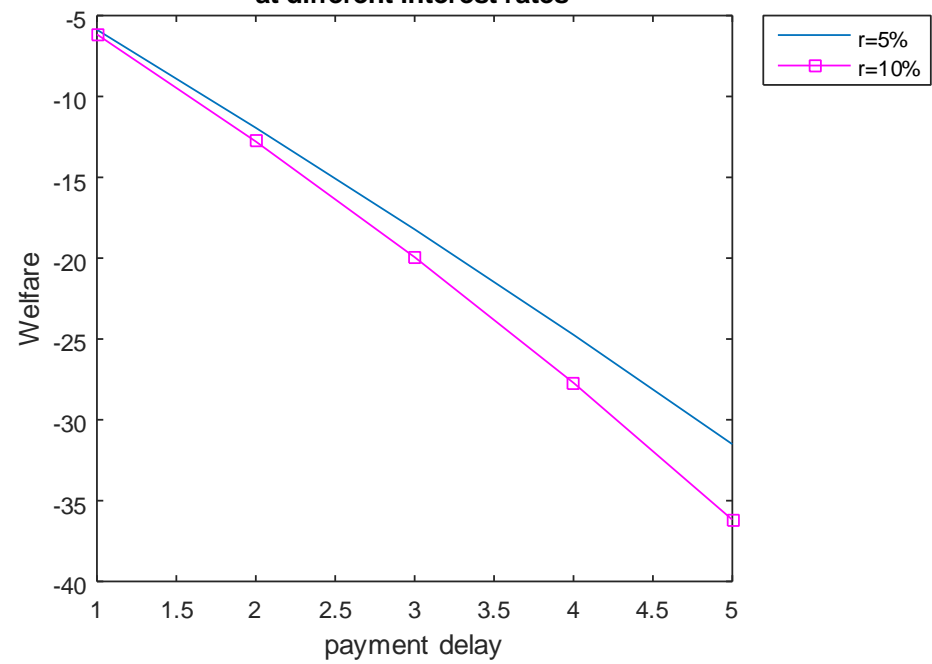

The upshot of this exercise is that a longer payment delay makes the borrower-household work longer in the employment. These households suffer an accelerated welfare loss as payment delay rises. The lender- households suffer less in terms of welfare due to his outside asset income as a cushion.

\subsection{Alternative employment option}

How does the labour supply behaviour of the adult change when he has an option to work for a non-NREGA job which has no payment delay? Let the labour supply for such a non-NREGA job be $n_{t}^{i}$. Let $\bar{n}$ be the exogenously given availability of such non-NREGA jobs. The production function facing this sector is given by a simple Cobb-Douglas form, $z n_{t}^{i \alpha}$ with $0<\alpha<1$ and $z$ is the exogenous total factor productivity in the non-NREGA sector. Without loss of generality, replace the non-labour income $y^{i}$ from the previous model by the income from non-NREGA employment. The wage $\widetilde{w}^{i}$ earned by the $i$ th household in such a non-NREGA job is determined by the profit maximizing risk neutral private employers.

The household now solves: 


$$
\begin{gathered}
\operatorname{Max} \sum_{t=0}^{\infty} \beta^{t}\left[\ln \left(c_{t}^{i}-\bar{c}\right)-A\left(l_{t}^{i}+n_{t}^{i}\right)\right] \\
c_{t}^{i}+b_{t}^{i}(1+r) \leq \widetilde{w}^{i} n_{t}^{i}+w l_{t-k+1}^{i}+b_{t+1}^{i} \\
l_{t}^{i} \leq \bar{l} \\
n_{t}^{i} \leq \bar{n}
\end{gathered}
$$

The first order conditions dictate the same consumption function (4) as before. Taking into account the possibility of corner solutions, the optimal stationary work allocation between non-NREGA and NREGA occupations are given by: ${ }^{17}$

$$
\text { Non-NREGA }: n^{i}(k)=\min \left[\bar{n},\left\{\frac{\alpha z}{\beta^{k-1} w}\right\}^{1 /(1-\alpha)}\right]
$$

NREGA: $\quad l^{i}(k)=\min \left[\bar{l}, \frac{\left(\bar{c}-\widetilde{w}^{i} n^{i}(k)\right) \beta\left(\beta^{-k}-1\right)}{(1-\beta) w}+\frac{1-\beta^{k}}{(1-\beta) A}+\frac{b_{0}^{i}\left(1-\beta^{k}\right)}{\beta^{k} w}\right]$

Given that there is a payment delay in the NREGA sector, the non-NREGA labour supply, (11) is determined by the arbitrage condition $\widetilde{w}^{i}=\alpha z\left(n_{t}^{i}\right)^{\alpha-1}=$ $\beta^{k-1} w$ when an interior solution exists; otherwise $n^{i}(k)=\bar{n}$. The nonNREGA labour supply does not depend on household's asset position while the NREGA participation,(12) does. As in Basu et al. (2009) lower TFP $(z)$ in the non-NREGA sector boosts NREGA participation by lowering the non-NREGA wage. On the other hand, a greater payment delay $(k)$ has an ambiguous effect on NREGA participation; $l^{i}(k)$. Since $n^{i}(k)$ is rising in $k$, the wage income from non-NREGA is also increasing in $k{ }^{18}$ This gives rise to a substitution effect that discourages NREGA participation in response

\footnotetext{
${ }^{17}$ The derivation is relegated to the Appendix.

${ }^{18}$ To see it, note that wage income from non-NREGA is given by: $\widetilde{w}^{i} n^{i}(k)=$ $\left(w \beta^{k-1}\right)^{-\alpha /(1-\alpha)} \cdot(\alpha z)^{1 /(1-\alpha)}$. which is increasing in $k$.
} 
to a higher $k$. On the other hand, a higher $k$ lowers the present value of deferred wages from NREGA that encourages the worker to work more in both sectors via an adverse wealth effect. The strength of this wealth effect depends heavily on the size of the household debt $\left(b_{0}^{i}\right)$. The effect of an increase in $k$ on NREGA participation is not obvious.

The NREGA labour supply response of the household to payment delay now crucially depends on the availability of outside labour market options which is given by $\bar{n}$ and his credit status $\left(b_{0}^{i}\right)$. For the sake of illustration, we set $\bar{n}=2$ for the lean season and $\bar{n}=8$ for the peak season. The rest of the parameters are kept the same as before. Figures 8 and 9 compare the household's labour supply responses in a lean season when the credit status differs. In a lean season due to insufficient private labour market opportunities, both borrower and lender households participate more in NREGA in response to longer payment lag.

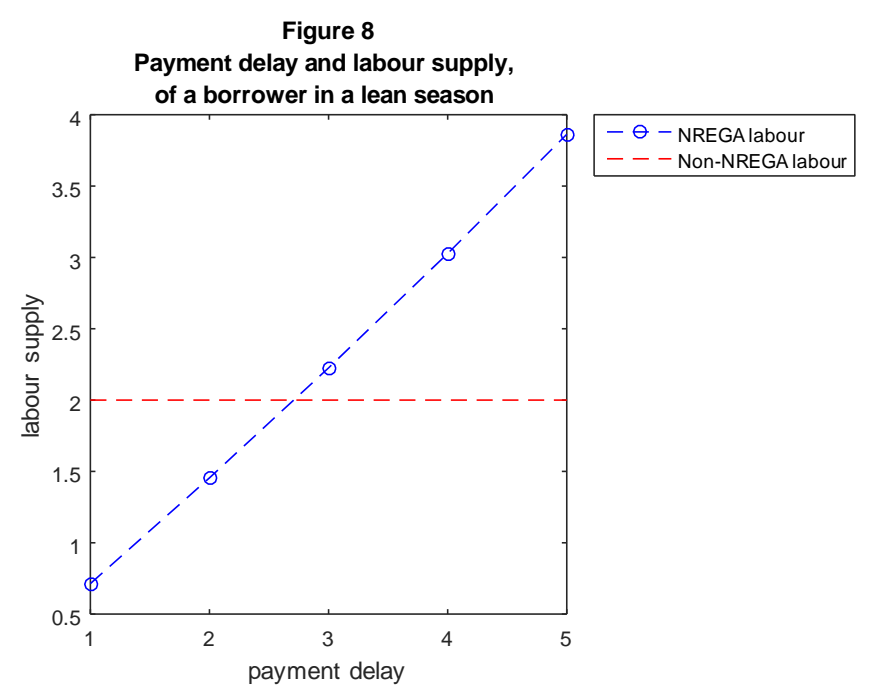




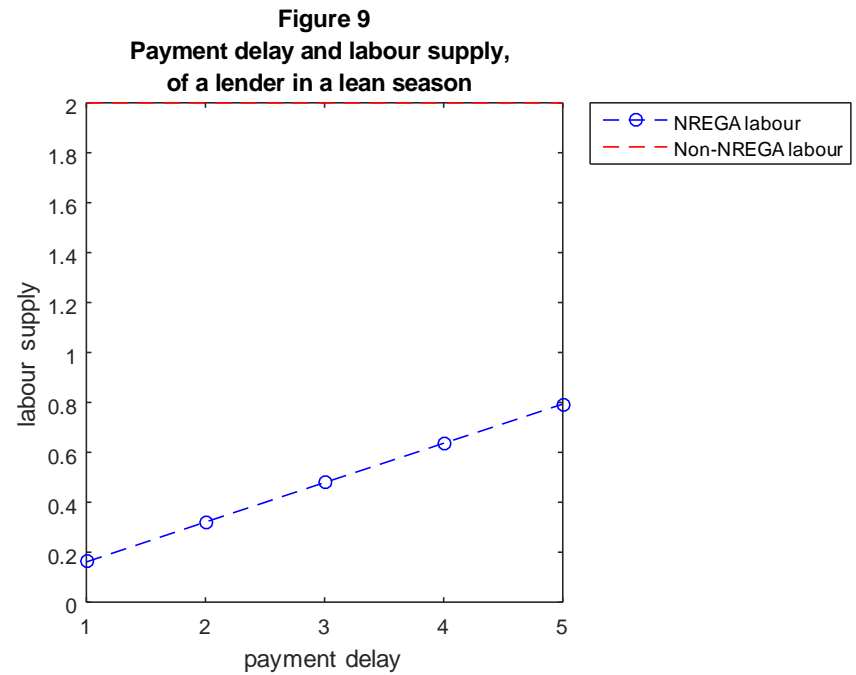

Figures 10 and 11 repeat the same experiment for the peak season. Both borrower and lender households behave similarly by increasing labour supply in both sectors as payment delay is longer. The response of the lenderhousehold to payment delay is less due to the asset cushion. ${ }^{19}$

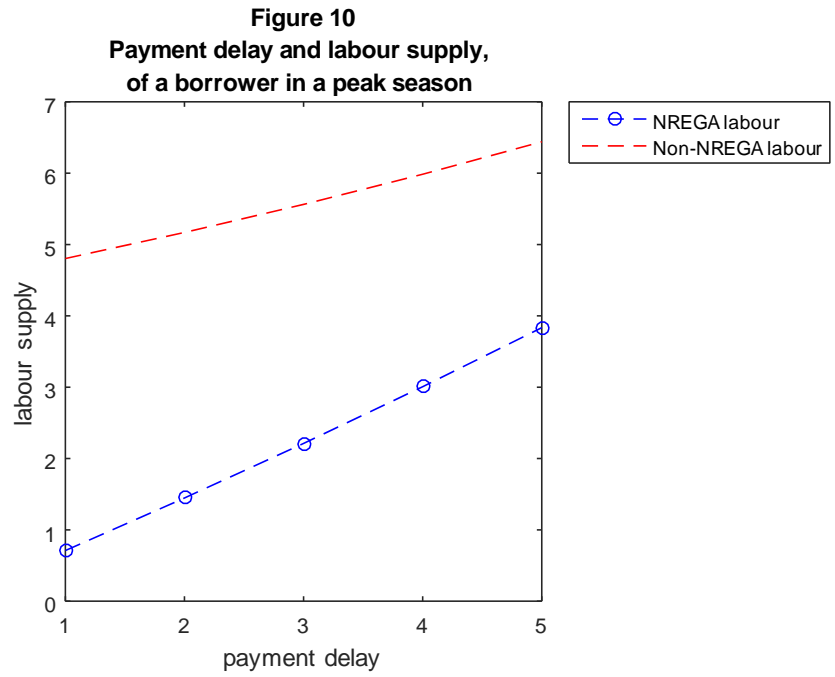

\footnotetext{
${ }^{19}$ Not surprisingly, giving greater asset position to the lender-household weakens his NREGA labour supply response to payment delay.
} 


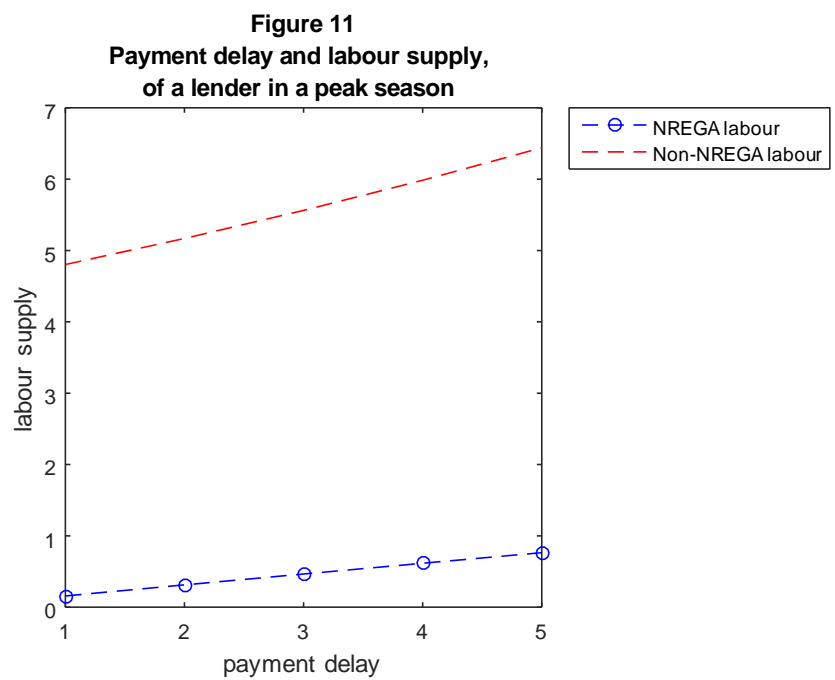

Table 2 reports the steady state welfare of the households in lean and peak periods according to their credit status and payment delay. ${ }^{20}$ In both lean and peak seasons the welfare loss due to payment delay is significantly higher for the borrower in contrast with the lender households.

$<$ Table 2 comes here $>$

In sum: if rural households have alternative employment options, the relationship between payment lag and NREGA labour supply response does not change much. Borrower household certainly increases labour supply to the NREGA when payment delay is longer. The labour supply response of the lender is sluggish. Both also experience greater loss of welfare due to payment delay.

\subsection{Connecting to Stylized Facts}

How does the model shed light on the two stylized facts reported in section 2 ? The key prediction of the model is that a borrower/household is likely to participate more in the NREGA to clear off his existing debt. This prediction holds in reasonably general environments which include outside employment

\footnotetext{
${ }^{20}$ The steady state welfare of the household in this case is given by: $W_{1}^{i}(k)=$ $\frac{1}{1-\beta}\left[\ln \left(A^{-1} w\right)+(k-1) \ln \beta-A\left(l^{i}(k)+n^{i}(k)\right]\right.$.
} 
options. Borrower-households work more in NREGA and suffer greater welfare loss due to longer payment delay compared to lender-households. Given that the NREGA programme is primarily targeted to poor and these programmes mostly help the poor in a slack season when outside employment options are less, our model is quite consistent with the first stylized fact.

The model has mixed implications about the second stylized fact. The goal of financial inclusion of the poor is to provide them a wider access to financial market and lower the borrowing cost by reducing their dependence on local money lenders who charge exorbitant interest rate. Our model implies that a lower borrowing cost would reduce NREGA participation because poor have to work less to retire the debt if the interest cost is lower. This could be welfare improving for the poor as well because it lowers the disutility of work. On the other hand, our model also predicts that income-poor households with greater indebtedness are likely to participate more in the NREGA programme. If financial inclusion of the poor actually elevates the indebtedness of the poor and if an NREGA programme with a formidable wage payment delay is in place, our model predicts that a higher debt burden would raise poor's participation in the programme to their detriment in terms of welfare. In this respect, our model is also consistent with the second stylized fact.

\section{Conclusion}

There is no dispute that an employment guarantee programme such as NREGA is a potentially useful anti-poverty measure to ameliorate the frictional unemployment arising from private labour markets, What is less obvious is how it helps the poor when such an employment guarantee programme has frictions of its own. In this paper, we focus on one such friction which is the wage payment delay. Our stylized facts based on district level data suggest that the NREGA participation actually responds positively to such a payment lag. This may misleadingly suggest that payment lag is not posing a threat to the efficacy of the workfare programme in India. We demonstrate in terms of a stylized life cycle model that an asset poor household 
without any outside employment option has no choice but to work harder in response to such a longer payment lag. This happens because a payment delay makes labour a credit good and the value of labour as an asset declines due to a longer payment lag. The household-borrower works harder to make a credible promise to the lender to pay off the existing debt obligations. The increased disutility of work and the deferred consumption due to longer payment lag make the household worker worse off. Although the official indicators of success of NREGA programme do not necessarily reveal this welfare loss of the poor, the anti-poverty goal of the workfare programme is defeated when payment delay is present. If a programme of financial inclusion raises rural indebtedness, a payment delay may compound the adverse welfare effect on the poor. The welfare loss resulting from the interaction of longer wage payment delay in NREGA and financialization of poor is robust when private labour market opportunities exist. The policy recommendation is the immediate reduction of the payment lag before implementing the financialization programme.

\section{A Appendix}

\section{A.1 Proof of proposition 1}

The Lagrangian of the problem is given by:

$$
\begin{aligned}
L^{p}= & \sum_{t=0}^{\infty} \beta^{t}\left[\ln \left(c_{t}^{i}-\bar{c}\right)-A l_{t}^{i}\right]+\sum_{t=0}^{\infty} \lambda_{t}\left[y^{i}+w l_{t-k+1}^{i}+b_{t+1}^{i}-c_{t}^{i}-b_{t}^{i}(1+r)\right] \\
& +\sum_{t=0}^{\infty} \mu_{t}\left[\bar{l}-l_{t}^{i}\right]
\end{aligned}
$$

where $\left\{\lambda_{t}\right\}$ and $\left\{\mu_{t}\right\}$ are the sequence of lagrange multipliers associated with the flow budget constraints and the inequality constraints. The first order 
conditions are given by:

$$
\begin{gathered}
\frac{\partial L^{p}}{\partial c_{t}^{i}}=\frac{\beta^{t}}{c_{t}^{i}-\bar{c}}-\lambda_{t}=0 \\
\frac{\partial L^{p}}{\partial l_{t}^{i}}=-A \beta^{t}+\lambda_{t+k-1} w-\mu_{t}=0 \\
\frac{\partial L^{p}}{\partial b_{t+1}^{i}}=-\lambda_{t}+\lambda_{t+1}(1+r)=0
\end{gathered}
$$

Assuming an interior solution $\left(\mu_{t}=0\right)$, use of (A.2) and (A.3) and yields

$$
A \beta^{t}=\frac{w \beta^{t+k-1}}{c_{t+k-1}-\bar{c}}
$$

which solves

$$
c_{t+k-1}=\bar{c}+\frac{w \beta^{k-1}}{A}
$$

Assuming the steady state condition $\beta(1+r)=1$,use of (A.2) and (A.4) yields $c_{t}^{i}=c_{t+1}^{i}$ for all t which after plugging into (A.5) yields the following stationary consumption policy

$$
c(k)=\bar{c}+\frac{w \beta^{k-1}}{A}
$$

In other words, the consumption is stationary because it does not depend on time but only on the payment lag, $k$. Using the flow budget constraint (3) recursively forward from date 0 and using the optimal stationary consumption function (4), one gets (assuming no-Ponzi game condition):

$$
\begin{aligned}
& -b_{0}^{i} \beta^{-1}+\frac{y^{i}}{1-\beta}+\beta^{k-1} w l(k)\left[1+\beta^{k}+\beta^{2 k}+\beta^{3 k}+\ldots . \infty\right. \\
= & {\left[\bar{c}+\frac{\beta^{k-1} w}{A}\right] \cdot \frac{1}{1-\beta} }
\end{aligned}
$$


which can be further simplified as

$$
-b_{0}^{i} \beta^{-1}+\frac{y^{i}}{1-\beta}+\frac{\beta^{k-1} w l(k)}{1-\beta^{k}}=\left[\bar{c}+\frac{\beta^{k-1} w}{A}\right] \cdot \frac{1}{1-\beta}
$$

to get the expression in the curly bracket in (5). The expression for $l^{i}(k)$ written in (5) takes into account the possibility of a corner solution when the

household desires to work longer than the limit $(\bar{l})$ set by the government.

\section{A.2 Case of labour supply at an intensive margin}

In this section, we analyze the case when the household supplies labour at an intensive margin. For simplification, we ignore the non-NREGA employment option of the household and assume that the non-labour income is exogenous again. The household now solves the following maximization problem.

$$
\operatorname{Max} \sum_{t=0}^{\infty} \beta^{t}\left[\ln \left(c_{t}^{i}-\bar{c}\right)+B \ln \left(1-h_{t}^{i}\right)\right]
$$

s.t.

$$
c_{t}^{i}+b_{t}^{i}(1+r)=y^{i}+w h_{t-k+1}^{i}+b_{t+1}^{i}
$$

where $h_{t}^{i}$ is labour hours which is a choice variable because the household now makes a choice of labour at the intensive margin.

Given the steady state assumption that $\beta(1+r)=1$, it is easy to verify from the Euler equation that the steady state consumption and labour supply depend only on the payment lag $k$ and is subject to the following restriction:

$$
c^{i}(k)=\bar{c}+\beta^{k-1} B^{-1} w\left(1-h^{i}(k)\right)
$$

Substitution of (A.9) in the life time budget constraint of the household 
with no-Ponzi game condition yields:

$$
h^{i}(k)=\frac{\beta^{-k} b_{0}^{i}+\left(\bar{c}-y^{i}\right) /\left\{(1-\beta) \beta^{k-1}\right\}+w B^{-1}(1-\beta)^{-1}}{w\left[\frac{1}{1-\beta^{k}}+\frac{1}{B(1-\beta)}\right]}
$$

It is easy to verify that $\frac{\partial h^{i}}{\partial k}>0$ if $b_{0}^{i}>0$ and $\bar{c}-y^{i}>0$ meaning $h^{i}(k)$ is unambiguously increasing in $k$ for poor indebted households. Thus greater payment delay increases labour supply.

Substitution of (A.9) in (A.10) yields the optimal consumption policy. Unlike the previous model, the consumption is not invariant to income. Since $h^{i}(k)$ is increasing in $k, c^{i}(k)$ is decreasing in $\mathrm{k}$. Thus the steady state welfare is decreasing in $k$. The key conclusion that a payment delay could increase the NREGA participation of the household member and make him worse off is thus a robust result which continues to hold in the case of this model where the household supplies labour at an intensive margin.

\section{A.3 Proof of eqs (11) and (12)}

The lagrangian of the problem is given by:

$$
\begin{aligned}
L_{1}^{p}= & \sum_{t=0}^{\infty} \beta^{t}\left[\ln \left(c_{t}^{i}-\bar{c}\right)-A\left(l_{t}^{i}+n_{t}^{i}\right)\right]+\sum_{t=0}^{\infty} \lambda_{t}\left[y^{i}+\widetilde{w}_{t} n_{t}^{i}+w l_{t-k+1}^{i}+b_{t+1}^{i}-c_{t}^{i}-b_{t}^{i}(1+r)\right] \\
& +\sum_{t=0}^{\infty} \mu_{t}\left[\bar{l}-l_{t}^{i}\right]+\sum_{t=0}^{\infty} \nu_{t}\left[\bar{n}-n_{t}^{i}\right]
\end{aligned}
$$

where $\nu_{t}$ is the lagrange multiplier associated with the inequality constraint (10).

The first order conditions are given by:

$$
\begin{gathered}
\frac{\partial L^{p}}{\partial c_{t}^{i}}=\frac{\beta^{t}}{c_{t}^{i}-\bar{c}}-\lambda_{t}=0 \\
\frac{\partial L^{p}}{\partial l_{t}^{i}}=-A \beta^{t}+\lambda_{t+k-1} w-\mu_{t}=0
\end{gathered}
$$




$$
\begin{gathered}
\frac{\partial L^{p}}{\partial n_{t}^{i}}=-A \beta^{t}+\lambda_{t} \widetilde{w}_{t}-\nu_{t}=0 \\
\frac{\partial L^{p}}{\partial b_{t+1}^{i}}=-\lambda_{t}+\lambda_{t+1}(1+r)=0
\end{gathered}
$$

Using (A.13) and (A.14), and assuming an interior solution, one solves for $n_{t}^{i}$ as in the curly bracket of $((11)$. The expression in (11) takes into account the possibility of a corner solution.

Using the same line of reasoning as in the proof of proposition, one can verify that the expression of $l^{i}(k)$ as in (12).

Finally, it is straightforward to verify from (A.12), (A.13) and (A.15) that the stationary solution for consumption is the same as (A.9). //

\section{References}

[1] Adhikari, A. and K. Bhatia (2010), "NREGA Wage Payments: Can we bank on the banks?", Economic and Political Weekly, Vol. XLV, No. 1, pp. 30-37.

[2] Banerjee, A., E. Duflo. C. Imbert, S. Matthew and R. Pande (2014), "Can E-Governance Reduce Capture of Public Programs? Experimental Evidence from a Financial Reform of India's Employment Guarantee", mimeo.

[3] Basu, A., N. Chau and R. Kanbur (2009), "A theory of employment guarantees: Contestability, credibility and distributional concerns", Journal of Public Economics, Vol. 93, pp. 482-497.

[4] Besley, T. and S. Coate (1992), "Workfare versus Welfare: Incentive Arguments for Work Requirements in Poverty-Alleviation Programs", American Economic Review, Vol. 82, No. 1, pp. 249-261.

[5] Crisil (2013), An Index to Measure India's Progress in Financial Inclusion, Delhi: CRISIL. 
[6] Dasgupta, A. (2014), "Can the Major Public Works Programme Serve as Buffer Against Negative Shocks? Evidence from Andhra Pradesh, India", mimeo.

[7] Desai, S, P. Vasishtha and O. Joshi (2015), "Mahathma Gandhi National Rural Employment Guarantee Act: A Catalyst fir Rural Transformation," NCAER, Delhi.

[8] Dreze, J. and A. Sen (1991), Hunger and Public Action, Oxford: Oxford University Press.

[9] Dupas, J. and J. Robinson (2013), "Why Don't the Poor Save More? Evidence from Health Savings Experiments", American Economic Review, Vol. 103, No. 4, pp. 1138-1171.

[10] Gang, I, K. Sen and M. Yun (2009), "Poverty in Rural India: Caste and Tribe", Review of Income and Wealth, Vol. 54, No. 1, pp. 50-70.

[11] Government of India (2013), The Mahatma Gandhi National Rural Employment Guarantee Scheme: Report to the People, New Delhi: Ministry of Rural Development.

[12] Government of India (2015), "MGNREGA Sameeksha II", Delhi: Orient Blackswan.

[13] Hulme, D. and M. Maitrot (2014), Has Microfinance Lost its Moral Compass?, Economic and Political Weekly, Vol. 49, No.48, pp. 30-48.

[14] Imbert, C. \& J. Papp (2015) "Labor Market Effects of Social Programs: Evidence from India's Employment Guarantee," American Economic Journal: Applied Economics, Vol.7(2), pp. 233-263.

[15] Khera, R. (2010), "Wages of Delay", Frontline, Vol. 27, Issue 10, pp. $1-7$.

[16] Kollmann, R., 2002. Monetary policy rules in the open economy: Effects on welfare and business cycles. Journal of Monetary Economics, pp. 989-1015. 
[17] Lal, R. , S. Miller, , M. Lieuw-Kie-Song and D. Kostzer (2010), "Public Works and Employment Programmes: Towards a Long-term Development Approach", UNDP Working Paper no. 66.

[18] Lipton, M. (1996), "Success in anti-poverty", Issues in Development Discussion Paper, vol. 8. International Labour Office, Geneva.

[19] Muralidharan, K., P. Niehaus and S. Sukhtankar (2015), "Building State Capacity: Evidence from Biometric Smartcards in India", mimeo.

[20] Nair, T.S. and A. Tankha (2014), "Inclusive Finance India Report 2014," Oxford University Press.

[21] Niehas, P. and S. Sukhtanker (2013), "The marginal rate of corruption in public programs: Evidence from India", Journal of Public Economics, Vol. 104, pp. 52-64.

[22] Ravallion, M. (1991) "Reaching the Rural Poor through Public Employment: Arguments, Evidence, and Lessons from South Asia", World Bank Research Observer, Vol. 6, pp. 153-76.

[23] Roy, I. (2015), "Class politics and social protection: the implementation of India's MGNREGA", ESID working paper no. 46, available at www.esid.org.uk.

[24] Sangwan. S.S. (2015), More Credit for Agricultural Households? NSSO's 70th Round on Indebtedness, Economic and Political Weekly, Vol. 50. No.16, pp. 23-24.

[25] Srinivasan, N (2011): Microfinance India: State of the Sector Report 2010 (New Delhi: Sage Publishers).

[26] Subbarao K., C. del Ninno, C. Andrews, and C. Rodriquez-Alas (2013), Public Works as a Safety Net: Design, Evidence and Implementation, Washington D.C.: The World Bank. 
Table 1: Payment Delay, Financial Inclusion and NREGA Participation:

Key Findings

\begin{tabular}{|l|l|l|l|l|l|}
\hline & Col. (1) & Col. (2) & Col. (3) & Col. (4) & Col. (5) \\
\hline$W P_{i}$ & $0.002^{* * *}$ & $0.002^{* * *}$ & $0.001^{* *}$ & $0.001^{* *}$ & 0.0002 \\
\hline Rainfall included? & No & Yes & Yes & Yes & Yes \\
\hline Other Controls & No & No & Yes & Yes & Yes \\
\hline State Fixed Effects & Yes & Yes & Yes & Yes & Yes \\
\hline R-square & 0.63 & 0.63 & 0.67 & 0.75 & 0.61 \\
\hline No of Observations & 498 & 498 & 453 & 177 & 276 \\
\hline Method of Estimation & OLS & OLS & OLS & OLS & OLS \\
\hline
\end{tabular}

Note: (a) Dependent variable is proportion of households participating in NREGA. The unit of analysis is the district; (b) Col. (3), (4) and (5): Other controls include measures of private labour demand at the district level. (c) Cols. (4) and (5): Results for the high financial inclusion districts are presented in Col. (4) and the results for the low financial inclusion districts are presented in Col. (5); (d) ** and ***: significant at 5 and 1 percent levels respectively; OLS $=$ ordinary least squares (e) All estimates with robust standard errors.

Table 2: Payment lag and Steady State Welfare of Households in Lean and Peak Seasons

\begin{tabular}{|l|l|l|l|l|l|}
\hline$k$ (Payment Lag) & 1 & 2 & 3 & 4 & 5 \\
\hline Lean Seasons & -27.1913 & -34.6558 & -42.4130 & -50.4831 & -58.8873 \\
\hline$W^{\text {bor row } e r}$ & -21.6650 & -23.3123 & -24.9462 & -26.5707 & -28.1900 \\
\hline$W^{\text {lender }}$ & -55.1942 & -66.2648 & -77.8955 & -90.1268 & -103.0013 \\
\hline Peak Seasons & -49.6679 & -54.9213 & -60.4287 & -66.2143 & -72.3040 \\
\hline$W^{\text {bor row er }}$ & $W^{\text {lender }}$ &
\end{tabular}

